\title{
Testimonios literarios de los orígenes del movimiento cristiano. Una introducción breve al Nuevo Testamento ${ }^{1}$
}

\section{Xavier Alegre,}

Facultat de teología de Cataluña, Barcelona, Centro Monseñor Romero, San Salvador.

\section{Introducción. Los orígenes del movimiento cristiano}

En el origen del movimiento cristiano, de sus Iglesias, está un hombre concreto, Jesús. Un campesino de la región marginada de Galilea, a comienzos de nuestra era ${ }^{2}$. Su país era una colonia pobre y oprinida del poderoso imperio romano.

Su lengua matema era el arameo, una lengua semita, emparentada con la lengua hebrea, que ya no gozaba de la proyección universal de la que había disfrutado unos siglos antes. La lengua y cultura dominante en el mundo del que su pars formaba parte era el griego. Es probable que si Jesús trabajo, como es plausible, en la ciudad vecina de Séforis, conocía (y hablaba) también el griego. Pero no era su lengua matema.

Su religión era la del pueblo de lsrael, centrada, por un lado, en tomo al Templo de Jerusalén; y, por otro, en unos libros, que recogían las tradiciones religiosas de este pueblo. Los cristianos denominamos este libro "el Antiguo (o Primer) Testamento", pues, con los escritos canónicos cristianos, a los que denominamos el "Nuevo (o Segundo) Testamento", forma parte ahora de "la Biblia" cristiana, es decir, de los

1. En el origen de este artículo está una ponencia que tuve en la Universitat Jaume I de Castcllı (España), en el marco del $I V$ encuentro diálogo fe-cultura: "Biblia y litera"ural". yute se lealizo el tr̃o 2001.

2. Sobre latsittilion de (i.lilea en aquella época puede verse S. Freyne, Galilee from Atember to Hairmm. IVitmington, 1980. 
libros o Biblioteca, que constituye la literatura sagrada del cristianismo. La literatura "biblica", por tanto, era un elemento constitutivo de su fe.

Su marco político era el imperio romano, pues vivía en unas provincias, Galilea y Judea, sometidas al imperio romano. $Y$ en medio de unas mayoŕas empobrecidas, que sufran claramente las consecuencias de la opresión económica del imperio y de sus colaboradores en Palestina. Por lo que reflejan los evangelios, Jesús fue particularmente sensible a este sufrimiento del pueblo. $Y$ le anunció la Buena Noticia de que el reinado de Dios (cfr. Mc 1,14-15), la liberación (cfr. Lc 4,16-20), estaban ya cercanos.

Pero no parece que Jesús escribiera nada (sólo Jn $8,6.8$ recuerda que escribió algo, pero "en la tierra"). Como tampoco lo hizo Sócrates, que fue inmortalizado por los escritos de Platón. Algo semejante ocurrió con Jesús. Fueron los escritos de sus discípulos los que dieron un impulso fundamental a su movimiento. Sobre todo los escritos que encontramos en lo que se ha denominado el Nuevo Testamento. Es un hecho significativo, por tanto, que en los orígenes del cristianismo estén unas obras literarias - me refiero al Nuevo Testamento- y que desempeñen en él un papel fundamental.

La pregunta es cómo se originó, entonces, la literatura del Nuevo Testamento y qué tipo de literatura encontramos en él.

\section{Los origenes del Nuevo Testamento}

Jesús murío, según parece, en la pascua del año $30 \mathrm{~d}$. C. Resultó ser un hombre tremendamente conflictivo para los poderes políticos, religiosos y económicos de su época (cfr. Mc 3, 6; 10, 17-27; 11, 15-19; 12, 12; 14, 1-2; Lc 16, 13). Murió denunciado por las autoridades religiosas legítimas de su pueblo (cfr. Mc 15,1$)^{3}$. Fue condenado al suplicio de la cruz por las autoridades romanas, como un terrorista más de aquellos tiempos (cfr. Mc 15, 2-15). Nadie apostó por él. Murió solo y abandonado por todos, a excepción de unas pocas mujeres, que le habian seguido desde Galilea (cfr. Mc 15, 40-41).

Su muerte ignominiosa provoco, obviamente, una crisis de fe en sus discípulos. Huyeron a Galilea, como puede deducirse de textos como Marcos 16, 7 o Mateo 28, 16-20. Los que lo habían condenado pensaron que habran acabado con él y con su movimiento religioso de protesta. Y se alegraron de ello, como el imperio romano se alegra, según Apocalipsis 11, 7-10, de la muerte de los testigos cristianos. Ellos habían muerto, precisamente, porque habían intentado ser fieles a su misión profética (cfr. Ap 11, 3-6) de anunciar al mundo, domina-

3. Sobre las causas que llevaron a Jesús a la muerte, puede verse mi artículo "Los responsables de la muerte de Jesús", Revista Latinoamericana de Teología, 14 (1997), 139-172. 
do por la injusticia que impone el imperio ( $c f r$. Ap 13), la buena noticia etema (cfr. Ap 14, 6; también Mc 13, 10) del triunfo definitivo de Dios.

Pero una experiencia impactante cambió radicalmente la vida de los primeros compañeros y compañeras de Jesús, y su manera de ver la realidad. Me refiero a la experiencia de que Jesús seguía realmente vivo, aunque ahora se hacía presente entre ellos de manera diferente a como lo habia hecho en su vida terrena. Se trató de aquello que los cristianos denominamos la "experiencia pascual". El Dios liberador del Éxodo (cfr. Ex 3, 7-10) había vuelto a intervenir -y esta vez de modo definitivo - , en la historia a favor de las víctimas - en este caso, a favor de Jesús, a quien resucitó de entre los muertos (cfr. Hch 3, 12-16). Esta experiencia influyó decisivamente, en la formación de la literatura del Nuevo Testamento.

Pero, ¿cómo fue esta experiencia? ¿Cómo podemos conocerla, si ninguno de nosotros estuvo allí presente? ${ }^{4}$.

No vamos a analizar ahora la experiencia pascual ${ }^{5}$, sino que vamos a considerar cuál es el marco que llevó al nacimiento del Nuevo Testamento para as! comprender mejor el significado de nacimiento del Nuevo Testamento como literatura. De hecho, sólo a través de la literatura tenemos hoy acceso, en cierto modo inmediato, a lo que debió ser esta experiencia pascual. Los testimonios literarios más antiguos de la misma los encontramos en diversos libros del Nuevo Testamento. Se encuentran en forma de confesiones de fe, de credos ( $c f r$. Rm 10, 9), o de himnos (cfr. Flp 2, 6-11).

Una confesión de fe muy antigua que encontramos en Primera Corintios 15 , 3-5 denomina aparición a la manera como Jesús resucitado se manifestó a sus discípulos. Para ello emplea una fómula literaria griega (ôpthê), que el Antiguo Testamento utilizaba para las manifestaciones de Dios. La fómula señala la iniciativa totalmente gratuita de Dios, en su aparición y que de Él sólo deja ver lo que el ser humano es capaz de ver6. El resucitado, por tanto, se manifiesta ahora "a la manera de Dios". Y esto es decisivo para la fe de la comunidad. Y al

4. Sobre la experiencia pascual de los primeros discípulos de Jesís, puede verse mi artículo "La fe cristiana en la resurrección", en M. Fraijo, X. Alegre y A. Tornos, $L a$ fe cristiana en la resurreccion": XXI Foro sobre el hecho religioso, Madrid y Santander, 1998, y la bibliograffa que alli indico.

5. Puede verse, por ejemplo, mi artículo "Perspectivas de la exégesis actual ante la resurrección de Jesús", en ibrd., pp. 33-62. Un estudio amplio y sólido de la resurrección se encuentra en la obra de H. Kessler, Las resurrección de Jesús. Aspectos brblico, reológico y sistemático, Salamanca, 1989, y en la de X. Léon-Dufour, Resurrección de Jesís y mensaje pascual, Salamanca, 1973. Desde la perspectiva latinoamericana, vale la pena consultar la obra de J. Sobrino, La fe en Jesucristo. Ensayo desde las vfctimas, Madrid, 1999, pp. 25-122.

6. Cfr. Alegre, "Perspectivas", pp. 43-45. 
mismo tiempo, muestra hasta qué punto Dios se ha identificado con esta víctima de la historia y, a través de él, con todas las víctimas (cfr. Mt 25, 31-46).

Más tarde, en una etapa ulterior de las comunidades cristianas, se crearon relatos (algunos de ellos los encontramos ahora en los evangelios) para explicitar literaria y teológicamente el significado de aquella experiencia para los cristianos que habian llegado a creer en Jesús (cfr. Lc 24; Jn 20$)^{7}$.

Pero sólo hay un testigo directo, Pablo, que, en sus cartas, nos habla de modo inmediato de esta experiencia. $Y$ lo hace utilizando diversos lenguajes literarios (el de revelación, el de aparición y el de transformación de la propia vida que ello implico) . $^{\mathbf{y}}$ Y ello es así porque Pablo es consciente de que, para expresar su vivencia, choca con una cierta "barrera del lenguaje", pues quiere explicar que Dios, por medio de Jesús resucitado, ha imumpido de modo sorprendente en su vida, cambiándola de un modo radical (cfr. Ga 1, 11-24; 1 Co 9 , 1; 15, 8-11; Flp 3, 7-14).

Ante esta experiencia pascual, los discípulos de Jesús regresaron a Jerusalén, convencidos de que estaban en los últimos tiempos. Como buenos creyentes judíos, pensaban que era el tiempo en el que Dios instauraría definitivamente su reinado, en la ciudad santa de Jenusalén. Por eso regresaron a esta ciudad, a la espera del fin del mundo. Y empezaron a hablar a los judios de aquella ciudad sobre la persona y el significado de Jesús de Nazaret, a quien Dios habra resucitado de entre los muertos, dándole así la razón contra sus adversarios. Eso es lo que reflejan los discursos de Pedro, que encontramos en Hechos 2, 22-24 ${ }^{10}$ o en $10,37-43^{\prime \prime}$.

7. Cfr. Alegre, "Perspectivas", pp. 50-56; J. Kremer, "El testimonio de la resurrección de Cristo en forma de narraciones históricas", Selecciones de reología, 28 (1989), 323-329.

B. Cfr. Alegre, "Perspectivas", pp. 43-49.

9. Cfr. J. Delorme, "La resurrección de Jesús en el lenguaje del Nuevo Testamento", en H. Cazelles (ed.), El lenguaje de la fe en la Escritura y en el mundo actual, Salamanca, 1973, pp. 109-140.

10. "Israelitas, escuchen: Jesús de Nazaret fue el hombre a quien Dios acreditó ante ustedes con los milagros, prodigios y señales que realizo por medio de él entre ustedes, como bien saben. Dios lo entregó conforme al plan que tenía previsto y determinado, pero ustedes, valiéndose de los impíos, lo crucificaron y lo mataron. Dios, sin embargo, lo resucit6, rompiendo las ataduras de la muerte, pues era imposible que esta lo retuviera en su poder".

11. "Ya conocen lo ocurrido en el pars de los judios, comenzando por Galilea, después del bautismo predicado por Juan. Me refiero a Jesús de Nazaret, a quien Dios ungió con Esplritu Santo y poder. Él pasó haciendo el bien y curando a los oprimidos por el demonio, porque Dios estaba con él. Nosotros somos testigos de todo lo que hizo en el país de los judíos y en Jerusalén. A él, a quien mataron colgándolo de un madero, Dios lo resucitó al tercer día y le concedió que se manifestase, no a todo el pueblo, 
Pero el fin del mundo no llegó con la inmediatez que ellos esperaban, una experiencia que queda reflejada en textos como Marcos $9,1^{12}$ y que él coloca antes del episodio de la transfiguración (cfr. Mc 9, 2-9) para poder resituar esta palabra de Jesús, que parecía que no se había cumplido.

Ante el retraso del retorno definitivo de Jesús al fin de los tiempos, la predicación cristiana se fue extendiendo, en el espacio y en el tiempo. A partir de ahí - y dado que los primeros testigos de la vida de Jesús iban muriendo-, se hizo necesario poner por escrito los textos fundamentales de la comunidad, a fin de evitar que el recuerdo de lo que Jesús hizo y dijo se fuera deformando con el tiempo. Y los animadores de las comunidades, muchos de ellos misioneros, tuvieron que escribir cartas para iluminar los puntos controvertidos en las comunidades, sobre todo cuando éstas no tenían acceso a los testigos inmediatos de Jesús y necesitaban orientación para resolver sus cuestiones y litigios. La literatura, por tanto, fue un fenómeno que marcó decisivamente el cristianismo. En este sentido, podríamos denominar el cristianismo - como a la religión judía anterior a él y a la musulmana que le siguió - una religión del libro.

Veamos ahora cómo fue naciendo, en este contexto, la literatura que encontramos en el Nuevo Testamento. La más antigua la hemos de deducir de los testimonios escritos que encontramos en el Nuevo Testamento. Me refiero a: (1) las confesiones de fe e himnos antiguos que encontramos en los diversos escritos del Nuevo Testamento; y (2) la colección perdida de palabras de Jesús (o "fuente Q") ${ }^{13}$, que, de algún modo, encontramos incorporada en los evangelios de Mateo y Lucas (que se han servido también del evangelio de Marcos para escribir sus obras). Ahora me limito a mencionar el hecho.

En todo caso, sobre todo dos son los tipos de literatura que fueron decisivos, en esta etapa. Me refiero a los escritos que denominamos "evangelios" y a las "cartas". Pero también fueron significativos otros dos escritos: los Hechos de los Apóstoles y el Apocalipsis de Juan. Para poderlos comprender mejor, veamos ante todo la matriz socioreligiosa de estos escritos, pues, entre otras cosas, hay que explicar, por ejemplo, por qué existen cuatro evangelios "canónicos" y no uno solo. $\mathrm{Y}$ por qué el Nuevo Testamento refleja en sus escritos unas iglesias

sino a los testigos elegidos de antemano por Dios, a nosotos que comimos y bebimos con él después que resucitó de entre los muertos. Él nos mandó predicar al puebio y dar testimonio de que Dios lo ha constituido juez de vivos y muertos. De él dan testimonio todos los profetas, afirmando que todo el que cree en el recibe el perdón de los pecados por medio de su nombre".

12. "Les aseguro que algunos de los aqui presentes no morirán sin haber visto antes que el reino de Dios ha llegado ya con poder".

13. Sobre la fuente $Q$ puede leerse J. Kloppenburg, The Formation of $Q$. Trajectories in Ancient Wisdom Collection, Philadelphia, 1987. 
cristianas tan plurales", aunque sin negar que todas ellas tienen un cierto "aire de familia", que distingue al Nuevo Testamento de otros escritos, como los gnósticos, muy cercanos a los orígenes cristianos.

\section{El nacimiento de las iglesias cristianas y el testimonio literario de las diversas etapas de los orígenes cristianos}

\subsection{La Iglesia "madre” de Jerusalén}

La ciudad de Jerusalén, a la que regresaron los discípulos, después de la experiencia pascual, era una ciudad bilingüe. Habŕa judíos de lengua aramea y judíos de lengua griega. Por ello, para celebrar y cultivar su fe, los judíos se reunían en sinagogas, en las cuales se lefa la Biblia en hebreo y se comentaba, parafraseaba, en arameo el texto que se acababa de leer (los Targums). $\mathrm{O}$ bien, en las sinagogas helenistas, se lefa la Biblia en alguna de sus traducciones griegas (por ejemplo, la denominada de los Setenta) y se comentaba, luego, el texto leído en esta lengua, que era la familiar a este grupo de creyentes judfos.

\section{Los primeros cristianos de lengua aramea}

Los primeros compañeros de Jesús (entre ellos los Doce) eran de lengua aramea. Por eso, los primeros en convertirse a su predicación eran también de lengua aramea. La primera comunidad cristiana, por tanto, que se originó en Jerusalén, hablaba esta lengua. Y se sentía profundamente judía en sus costumbres religiosas. Participaba en el culto en el Templo ( $c f r$. Hch 2, 46-47) y podía ser vista por sus conciudadanos como un grupo (o secta) judio, que creía que Jesús de Nazaret era realmente el Mesías esperado por Israel.

Los primeros cristianos eran, pues, y se sentían judíos de religión. No eran aún conscientes de la "novedad" cristiana, inaugurada con la muerte de Jesús en la cruz, una novedad que aparecerá más tarde, en textos como Marcos 2, 21-22, en el marco de un grupo de controversias, que muestra la distancia entre la interpretación de la ley que es propia de Jesús y la que realizan los fariseos judíos.

En esta etapa inicial, Pedro y el resto de los Doce jugaron un papel importante. Pero, poco después, ocurre un hecho significativo. Santiago, el hermano de Jesús ( $c f r$. Ga 1, 19), que no era miembro de los Doce y se distingura por su profunda religiosidad judía, pasó a liderar esta comunidad (cfr. Ga 2, 9; Hch 15, 13-21; 21, 18ss). Sorprendentemente este grupo en tomo a Santiago, y esta Iglesia, que siguió viviendo en Jerusalén hasta su destrucción, el año $70 \mathrm{~d}$. C.,

14. A tomar conciencia de este hecho tan significativo ayuda mucho la obra de $R$. E. Brown, Las iglesias que los apóstoles nos dejaron, Bilbao, 1986. Puede verse también X. Alegre, "El movimiento de Jesús y las primeras comunidades cristianas", que ahora se encuentra en Memoria subversiva y esperanza para los pueblos crucificados, Madrid, 2003. pp. 201-238. 
por las tropas romanas, no ha dejado ningún escrito normativo significativo en el Nuevo Testamento. Por eso, su interpretación "conservadora" de la fe no se convirtió en normativa para el cristianismo. Este hecho puede servir de toque de atención para todas las iglesias que se niegan a aceptar los signos de los tiempos y a inculturar adecuadamente la fe.

\section{Los primeros cristianos de lengua griega}

Pero pronto se convirtieron también judíos de lengua griega. Su propia cultura y la genialidad teológica de sus líderes - el más significativo fue Esteban- les ayudó a tomar conciencia de la novedad cristiana y de que el Templo de Jerusalén ya no era significativo ( $c f r$. Hch 7), como no lo había sido para Jesús de Nazaret (cfr. Mc 11, 15-19). Y empezaron a relativizar las leyes de pureza cultual judías, que dificultaban la misión y la universalidad cristianas. Su modo de interpretar el Antiguo Testamento y el significado de Jesús resultaron novedosos e innovadores.

\section{El primer conflicto entre cristianos}

Los cristianos judfos de lengua aramea, más conservadores, se inquietaron ante esta interpretación. Surgieron tensiones entre ambas comunidades. Lucas lo refleja muy bien en Hechos 6, 1-7, aunque disimulando el conflicto real, que era teológico. Lo disimula porque los Hechos de los apostoles quieren ser una presentación teológica de lo que fueron las primeras comunidades cristianas. Pero lo hace destacando lo que éstas tenfan de modélico para que sirvieran de ejemplo a sus comunidades, que ya vivian en otra época y empezaban a tener conflictos intermos serios. Por eso Lucas tiene la tendencia a ocultar los defectos de la primera comunidad. En vez de presentar la tensión como lo que fue, es decir, como un conflicto teológico serio, lo presenta como un conflicto económico. Dice que las viudas de los cristianos judíos de lengua griega se sentían marginadas en el campo que hoy denominamos la Caritas (cfr. Hch 6, 1).

Para resolver el conflicto, los Doce, según lo que nos cuenta Lucas, en los Hechos de los apossoles, convocan a la comunidad de Jerusalén (cfr. Hch 6, 2). La convocación de toda la comunidad era un hecho que, por lo visto, fue bastante común en muchas comunidades cristianas primitivas, a juzgar por el hecho que Pablo dirige sus cartas a toda la comunidad para que ésta resuelva sus conflictos internos ( $c f r$. 1Co 15) o por lo que se dice en el discurso eclesial de Mateo (cfr. Mt 18). En esta reunión de Jerusalén, a la que antes he aludido, se decide que los Doce Apóstoles se dedicarán al "anuncio de la Palabra", mientras que el servicio caritativo de las mesas lo realizarán "siete hombres de buena reputación, llenos del Espíiu Santo y de sabiduría". Todos estos "servidores" o "diáconos"Is llevan nombres griegos y uno de ellos, Nicolás, ya es de origen pagano (cfr. Hch 6, 2-6).

15. ¡Pablo se da a sí mismo el título también de diácono en $\mathrm{Rm}$ I, 1 ! 
Pero la realidad que refleja este conflicto tuvo que ser otra, pues, si seguimos leyendo los Hechos de los apóstoles, vemos que al líder de los siete ${ }^{16}$ diáconos, Esteban, los judios no cristianos lo hacen asesinar. Pero no lo condenan por haber administrado mal los bienes de la comunidad, sino por su predicación sobre Jesús, muy crítica con el Templo de Jerusalén y con la interpretación judía del Antiguo Testamento ( $c f r$. Hch 6, 8-7, 60). Y otro diácono, Felipe, aparece en Hechos 8, 4ss. enseñando y bautizando. Los diáconos son, por tanto, los líderes religiosos del grupo de la comunidad de Jerusalén de lengua griega.

Los Doce, preocupados por la unidad de la comunidad cristiana, aceptan y sancionan este liderazgo. Al fin y al cabo, Jesús no había decidido nada sobre el modo cómo debían estructurarse las iglesias que nacieran después de pascua ${ }^{17}$. Por ello, los Doce respetan el incipiente pluralismo de las iglesias cristianas y el que las comunidades elijan sus líderes. Eso explica que, según Lucas, los líderes helenistas sean siete. Se trata, como indiqué, de un número simbólico. El número doce, estaba ocupado ya por los discípulos que Jesús escogió como signo de que venía a reconstituir el pueblo de Israel y la alianza. En todo caso, ambos números simbolizan la "nueva alianza", que realiza Dios con su pueblo y con la humanidad, a través de la Iglesia cristiana. Pues las iglesias cristianas son muy conscientes de su entronque con el pueblo de Israel, escogido por Dios para realizar su proyecto universal de liberación a favor de los pobres y marginados de toda la humanidad. Ellas se sienten ahora el "reino de sacerdotes" (1Pe 2, 9; Ap 1, 6; la imagen está tomada de Ex 19, 6, un texto que se encuentra en el marco de la alianza de Dios con su pueblo).

\section{La primera persecución contra los cristianos}

Esa interpretación "helenista" más radical del proyecto de Jesús, cuestionando - como ya lo había hecho Jesús - determinados modos de interpretar y de vivir la fe de Israel, tenía que entrar pronto en conflicto con los judíos no cristianos más conservadores. No olvidemos que se estaba gestando la guerra judía contra Roma de los años 66-70 y que la religión era el elemento fundamental, que daba identidad al pueblo de Israel. Cuestionar el culto en el Templo, la celebración del sábado o las leyes cultuales judías resultaba para muchos un auténtico escándalo, un ataque a la identidad de Israel. Por eso se desencadenó la persecución contra este grupo. Una persecución que desembocó en el asesinato de Esteban (cfr. Hch 7, 1-60). Y, luego, en la persecución contra todo el

16. El número es, obviamente, simbolico: indica plenitud y recuerda la alianza del pueblo de Dios.

17. Cfr. lo que digo sobre el proyecto de Jesús y la Iglesia, en mi artículo "Utopía: la Iglesia tal como Jesús la querfa", en Memoria subversiva y esperanza para los pueblos crucificados, Madrid, 2003, pp. 171-200. 
grupo helenista, por lo que éste se dispersó y empezó la misión fuera de Judea (cfr. Heh 8).

En cambio, los líderes iniciales y fundamentales de la Iglesia de Jerusalén (los Doce) no fueron perseguidos, ni tuvieron que dejar Jerusalén (cfr. Hch 8, 1). En principio, este hecho resulta sorprendente. Pero ello fue así porque los dirigentes judíos no veían que ellos cuestionaran la identidad religiosa judía.

La dispersión y misión realizada por los cristianos de la línea más abierta e innovadora ayuda a entender, entonces, por qué todos los escritos del Nuevo Testamento reflejan, fundamentalmente, la línea abierta de la Iglesia cristiana. La Iglesia de Jerusalén y los cristianos judíos conservadores se quedaron muy pronto en la minoría. Y su interpretación de la fe cristiana no fue asumida por las grandes iglesias cristianas. Por ello se quedó sin literatura significativa, que sirviera de noma para todas las iglesias cristianas.

\subsection{La Iglesia de Antioquía}

Misioneros cristianos helenistas predicaron en Antioquía (cfr. Hch 11, 19ss), una ciudad importante, en el imperio romano (junto con Roma y Alejandría). En la ciudad existía una numerosa colonia judía. Un buen número se convirtió al cristianismo. Pero mantuvieron la línea teológica abierta, propia de los misioneros de la línea helenista. Por eso, el grupo de cristianos que provenían del paganismo y pasó a formar parte de esta Iglesia fue cada vez más numeroso. Pues no se les obligaba a circuncidarse, ni a cumplir con las nommas de pureza cultual judías. Y eso facilitaba su conversión.

Por ello pronto quedó claro que la Iglesia de Antioquía no era, sin más, un grupo o secta judía, sino, en cierto modo, una religión propia. Por eso fue en Antioquía donde por primera vez se denomino "cristianos" a los seguidores de Jesús (cfr. Hch 11, 26). Cuando un hombre tan significativo para el cristianismo como Pablo se convirtio, fue incorporado por Bemabé a esta comunidad (cfr. Hch $11,25 s)$ y se convirtió en uno de sus líderes teológicos y en un gran misionero ( $c f r$. Hch 13). Y eso dio nuevas alas al movimiento cristiano abierto.

\section{El "concilio" de Jerusalén}

La comunidad creció, entonces, desarrollando la nueva identidad eclesial muy abierta a las personas de origen pagano. Esto inquietó a la comunidad "madre" de Jerusalén, que vio en este hecho un cuestionamiento de su identidad judía y una dificultad para su predicación entre los judíos. Le pareció una devaluación del auténtico cristianismo.

Para resolver el nuevo conflicto teológico, la comunidad de Antioquía delegó a tres de sus miembros, dos de origen judro (Bernabe y Pablo) y uno de origen pagano (Tito), para que fueran a Jerusajén y trataran de resolver, por medio del 
diálogo, el conflicto. El único testimonio directo de un testigo presencial de este encuentro lo hallamos en Pablo. Concretamente en Gálatas 2, 1-10. Según él, la conversación con los dirigentes de la Iglesia de Jerusalén (y de modo especial con Santiago, Pedro y Juan) llevó a que éstos aceptaran como legitima la manera como se vivía el cristianismo en Antioquía. Por ello, en este encuentro de Jerusalén, se encargó a Pedro que liderara la misión entre los judíos, mientras que Pablo se encargaría de la mision entre los paganos (cfr. Ga 2, 7-8). En todo caso, no se consideró necesario que la comunidad de Antioquía circuncidara a los paganos que se convirtieran, ni que impusiera ninguna obligación cultual judía a sus miembros. Sólo se les pidió la solidaridad económica, en señal de comunión entre las iglesias que ya no eran especificamente judjas y la Iglesia madre de Jerusalén ( $c f r$. Ga 2,10$)^{18}$.

Todo parece indicar que fue en esta Iglesia de Antioquía, hacia los años 80 (y por tanto, después del conflicto teológico entre Pedro y Pablo del que hablaré a continuación), donde se escribió el evangelio de Mateo. El evangelio reflejaría la postura teológica de Pedro y de la comunidad de Antioquía, una vez Pablo se ha independizado de ella y se ha dedicado con empeño a la creación de iglesias fundamentalmente formadas por cristianos de proveniencia pagana, que no aceptan ya la religiosidad cúltica judra y sus prescripciones. Antioquía, en cambio, mantiene la novedad cristiana (cfr. Mt 9,10-17), pero esforzándose aún más que Pablo por mostrar la continuidad con el Antiguo Testamento (cfr. Mt 5, 17-20).

\subsection{Las igleslas paulinas}

La Iglesia de Antioquía pareció respirar con la decisión "aperturista" del "concilio de Jerusalén". Y cuando Pedro llegó a ella, cumpliendo con el encargo recibido en Jerusalén de ser el líder de la misión entre los judíos (un buen grupo de la comunidad era de origen judío y en Antioquía había muchos judíos no cristianos), tomo en serio las decisiones del "concilio de Jerusalen". Por ello, Pedro compartía sin problemas la mesa con los cristianos de origen pagano, sin preocuparse de las nomas de pureza cultual judía, que lo prohibían. Según la teologra judía, comer con alguien que no cumplía con las normas de pureza cultual convertía en impuro al que lo hacía (cfr. Mc 2, 15-17), dificultando cualquier relación con los judfos. Pedro sabra que la reunión de Jerusalén habra

18. Lucas presenta una versión ulterior -y menos precisa históricamente- de este encuentro, que ha sido denominado el "concilio de Jerusalen" (cfr. Hch 15). Sobre el significado de este encuentro puede leerse J. Gnilka, Pablo de Tarso. Apdstol y testigo, Barcelona, 1998, pp. 101-107; J. S. Upkong y Asahu-Ejere, "La carta a los Gálatas y el problema del pluralismo cultural en el cristianismo", Selecciones de Teologia, 29 (1990), 97-102; M. de Burgos, Pablo, predicador del evangelio, Salamanca, 1999, pp. 77 82 (más las pp. 83-87, donde el autor hace notar que el decreto de Hch 15 es posterior al encuentro de Jerusalén, ya que, de hecho, Pablo no lo conoce en Hch 21, 17-26). 
relativizado este aspecto, y por eso, se sentra autorizado, al llegar a Antioguía, para actuar con esta libertad cristiana, que relativizaba las normas judías de pureza cultual.

Pero cuando llegaron a la comunidad algunos cristianos de la línea teológica de la Iglesia de Santiago (Jerusalén) y le criticaron que, siendo el líder de la misión entre los judios, hubiera renunciado a vivir de acuerdo con las normas religiosas judías, Pedro cedió a sus presiones. Pedro era de talante más bien conciliador y quiso evitar problemas con la Iglesia de Jerusalén, que se encontraría en dificultades con los judíos no cristianos por la manera como la Iglesia de Jerusalén se relacionaba con las iglesias paganocristianas, ya que toleraba su apertura a los paganos, sin obligarles a vivir al modo judío.

Pero la actitud de Pedro cré entonces dificultades a la postura teológica defendida por Pablo, que no era tan conciliador. Pues Pedro podía dar la impresión - con su liderazgo indiscutible por haber sido el portavoz de los Doce, en tiempos de Jesús (cfr. Mc 8, 29) y el primer testigo de la resurrección de Jesús (cfr. 1Co 15,5 y Lc 24,34$)^{19}-$, de que para poder ser un buen cristiano había que ser también judío de religión. Es decir, por lo menos se cuestionaba la libertad cristiana con respecto a la Ley, lo que Pablo había deducido del significado profundo de la muerte de Jesús en la cruz (cfr. Ga 2,15s). Y podía parecer que el cristiano que vivía la religión judía era mejor que el que no la vivía. Se cuestionaba, por tanto, para Pablo, el pluralismo eclesial que él con tanto ahínco había defendido, en el encuentro de Jerusalén. Se negaba un principio teológico paulino fundamental, que él formula así en Gálatas 3, 26-28: "Efectivamente, todos ustedes son hijos de Dios por la fe en Cristo Jesús, pues todos los que han sido bautizados en Cristo, de Cristo han sido revestidos. Ya no hay distinción entre judío o no judío, entre esclavo o libre, entre varón o mujer, porque ustedes son uno en Cristo Jesús". Por eso, Pablo no puede callar ante la actitud de Pedro. Y le reprende públicamente delante de toda la comunidad, como recuerda Pablo en Gálatas 2, 11-14:

Pero cuando Pedro llegó a Antioquía [después del encuentro de Jerusalén, mencionado en $\mathrm{Ga} 2,1-10$ ], tuve que enfrentarme abiertamente con él a causa de su inadecuado proceder. En efecto, antes de que vinieran algunos de los de Santiago, no tenía reparo en comer con los de origen pagano; pero cuando vinieron, comenzó a retraerse y apartarse por miedo a los partidarios de la circuncisión. Los demás judíos lo imitaron en esta actitud, y hasta el mismo Bernabé se dejó arrastrar por ella. Viendo, pues, que su proceder no se ajustaba a la verdad del evangelio, dije a Pedro en presencia de todos: "Si

19. No considero aquí la tradición juánica, que coloca a Maŕa como primer testigo de las apariciones de Jesús ( $c f r$. In $20,11-18$ ) y considera al "discípulo amado" como primer creyente en la resurrección de Jesús (cfr. Jn 20, 8-9). 
tú, que eres judro, vives como pagano y no como judío, ¿por qué obligas a los de origen pagano a comportarse como judíos?".

Como se ve por este texto, la mayoría de la comunidad de Antioquía dio apoyo a la postura de Pedro. Por ello, Pablo, sin romper la comunión fundamental con Pedro y la Iglesia de Antioquía (su oposición a las divisiones aparece muy clara en 1Co 1, 10-13), decide dejar la comunidad de Antioquia y empezar una mision que posibilitase unas iglesias, en las cuales la religiosidad judía sea, de entrada, algo absolutamente secundario y más bien negativo.

Testimonio de este modo nuevo de ser Iglesia lo encontramos en las cartas auténticas de Pablo, entre las cuales destacan Gálatas y Filipenses, por su conflicto con la religiosidad judia y con aquellos judíos cristianos que quieren rejudaizar a las iglesias. En todas estas cartas (por orden probable de aparición serfan $1^{\mathrm{a}}$ Tesalonicenses, $1^{\mathrm{a}}$ y $2^{\mathrm{a}}$ a los Corintios, Filipenses, Filemón, Gálatas y Romanos) descubrimos el testimonio literario de los inicios de la fe cristiana y de las dificultades que vivieron las iglesias cristianas paulinas. La más significativa de estas cartas es la que va dirigida a los Romanos, pues es como el testamento teológico del Apóstol, cuando está a punto de ir a la Iglesia de Jerusalén (cfr. Rm 15, 25-31) ${ }^{20}$. La escribe para defender la legitimidad de sus iglesias paulinas y la comunión de éstas con la Iglesia madre de Jerusalén, por medio de la entrega de la colecta convenida ( $c f r . \mathrm{Ga} 2,10$ ), en el "concilio de Jerusalén". En las cartas paulinas aparece la genialidad teológica y misionera de Pablo. Y también el posible influjo de la retórica griega, en su modo de escribir. En todo caso, las cartas de Pablo son expresión del esfuerzo que hizo el Apóstol por inculturar la fe cristiana, en el entorno helenista y urbano que él vivi6 ${ }^{21}$.

En la esfera de la teología paulina, aunque está escrito hacia el año 70 , varios años después de la muerte de Pablo, podríamos colocar al evangelio de Marcos, que está en profunda sintonfa con el pensamiento teológico del apóstol ${ }^{22}$. Su

20. "En este momento estoy a punto de salir para Jenusalén, a fin de prestar un servicio a aquellos creyentes, pues los de Macedonia y Acaya han tenido a bien hacer una colecta en favor de los creyentes necesitados de Jerusalén. Han tenido a bien, aunque en realidad se trataba de una deuda, pues si los paganos han participado de sus bienes espirituales, justo es que los ayuden en lo material. Una vez cumplida esta misión y entregado el fruto de esa colecta, partiré para España pasando por su ciudad. Y sé que, al ir a verles, lo haré con la plena bendición de Cristo. Por lo demás, hermanos, les ruego por nuestro Señor Jesucristo, y por el amor que el Espíritu ha derramado en nosotros, que pidan encarecidamente a Dios por mí, para que no caiga en manos de los que en Judea se oponen a la fe, y esta ayuda que llevo a Jerusalén tenga buena acogida por parte de los creyentes".

21. Cfr. Meeks ,W. A., Los primeros cristianos urbanos. El mundo social del Apostol Pablo, Salamanca, 1988.

22. Cfr. J. Marcus, "Mark, Interpreter of Paul", New Testament Studies, 46 (2000), pp. 473-487; Id., Mark 1-8, New York, 2000, pp. 73-75; cfr. también M. D. Goulder, 
gran aportación es (como veremos más adelante) haber recuperado lo que fue concretamente la vida de Jesús, que le llevó a la cruz y a la resurrección, como criterio de discernimiento fundamental para saber en qué consiste realmente el seguimiento de Jesús.

Después de su muerte, sus discípulos intentarán resolver los nuevos problemas que se van planteando a las iglesias, apoyándose en su autoridad. Por eso le atribuyen las cartas que ellos escriben. El fenómeno de la pseudonimia era bien visto en aquella época. Pienso concretamente en la $2^{\mathbf{a}}$ carta a los Tesalonicenses, en las cartas a los Colosenses y a los Efesios, y en las cartas $1^{\mathrm{a}}$ y $2^{\mathrm{a}}$ a Timoteo y a Tito. Los discípulos de Pablo son muy conscientes de la importancia que puede tener el género literario carta para orientar a las comunidades, que se ven amenazadas por diversos peligros e inquietudes. Por eso, imitan el ejemplo de Pablo.

También el evangelio de Lucas o la $1^{\mathrm{a}}$ carta de Pedro estarían marcados por el influjo de la teología paulina, aunque responden a una situación eclesial ulterior a la acción (conflictiva) del apóstol de los paganos.

\subsection{El evangelio y las cartas de Juan}

La literatura que la tradición atribuye a Juan, aunque recoge tradiciones antiguas, pertenece a una etapa bastante tardía de los comienzos del cristianismo. El evangelio recibiŕa su redacción definitiva hacia finales del siglo I d. C. Sería un exponente literario de sucesivas relecturas de las tradiciones sobre Jesús que recoge Juan. $Y$ las cartas, por lo menos la $1^{4}$, serían posteriores al evangelio ${ }^{23}$.

Detrás del evangelio se encuentra un gran teólogo, que ha sido capaz de formular con más claridad el profundo misterio de la persona de Jesús y su relación única con Dios Padre.

La Iglesia a la que va dirigida la literatura juánica es de origen judeocristiano, de lengua griega y abierta a la integración de los paganos, en la comunidad ( $c f r$. Jn 12, 32s). Su fe en la divinidad de Jesús, que culmina en la confesión de fe "Señor mío y Dios mío" (Jn 20, 28), que el cuarto evangelio pone en boca de Tomás, en el momento en que Jesús resucitado se le aparece, llevó a la comunidad a un profundo conflicto con los judíos no cristianos, que exclúan a los cristianos

"Those Outside (Mk. 4,10-12)", Novum Testamentum, (1991), pp. 289-302; J. R. Donahue "The Quest for the Community of Mark's Gospel", en The Four Gospels 1992. Fs. F. Neirynck (ed. F. van Segbroeck et al.), Leuven, 1992, 2.817-38; W. Schenk, "Sekundäre Jesuanisienungen von primären Paulus-Aussagen bei Markus", The Four Gospels 1992, 2.877-904; J. R. Donahue, "Windows and Mirrors: The Serting of Mark's Gospel", Catholic Biblical Quarterly, 57 (1995), 1-26.

23. Sobre la formación de los escritos joánicos, cfr. mi artículo "La tradición joánica y su evolución. Un llamado a saber conjugar la fidelidad a Jesús con la creatividad del Espíritu en la Iglesia", Revista Latinoamericana de Teologia, XVII (2000), 117-142. 
juánicos de la sinagoga ( $c f r$. Jn 9,$22 ; 12,42$ ). En numerosos diálogos $-\mathrm{y}$ utilizando la ironfa literaria y la técnica del malentendido-, el autor del evangelio va desarrollando pedagógicamente su teología novedosa.

Pero esta teología provocó también el cisma dentro de la comunidad. La confesión de la divinidad de Jesús llevó a algunos miembros de la comunidad a negar que Jesús hubiera sido realmente un ser humano ( $c f r .1$ Jn 4, 1-3). Por eso, un discípulo, que se denomina a sí mismo el "anciano" o presbítero (cfr. 2Jn 1, 1; 3In 1), tiene que escribir una carta para corregir lo que él considera una grave deformación "espiritualista" de la fe cristiana, que lleva a no amar al hermano "a quien se ve" con la excusa de que ya se ama a Dios (cfr. 1Jn 3, 11-17; 4, 19-21).

\subsection{Las iglesias gnósticas "disidentes" de las grandes iglesias cristianas}

Junto a los escritos que llegaron a formar parte del Nuevo Testamento, conocíarnos ya desde la época de los padres de la Iglesia la existencia de una serie de escritos, que no fueron aceptados, ni considerados como inspirados por Dios, por estos padres y por la mayoría de las grandes iglesias cristianas. San Ireneo, por ejemplo, había escrito su obra Adversus Haereses para combatir las ideas de estos grupos, que se alejaban de las interpretaciones plurales, pero coincidentes en lo fundamental, de las grandes iglesias cristianas, que encontramos testimoniadas en el Nuevo Testamento. Lamentablemente, durante mucho tiempo apenas se conocían los escritos originales de este grupo de pensadores cristianos.

Pero después de la segunda guerra mundial, la situación cambió radicalmente. En diciembre de 1945, un campesino árabe hizo un descubrimiento sorprendente, en un lugar llamado Nag Hammadi, en el Alto Egipto ${ }^{24}$. Desde entonces, tenemos la posibilidad de conocer muchos de estos textos, entre ellos evangelios como el de Tomás, el de María, el de Pedro, el de Felipe o el Protoevangelio de Santiago ${ }^{25}$. Y apocalipsis como el de Pedro. Son obras que se diferencian bastante de los textos canónicos, encabezados por un evangelio tan significativo y antiguo (escrito hacia el año 70) como el de Marcos.

24. Cfr. el relato de los descubrimientos en E. Pagels, Los evangelios gnósticos, Barcelona, 1982, pp. Ilss. Una breve y sencilla introducción a la Gnosis la encontramos en C. Markschies, La Gnosis, Barcelona, 2002.

25. El Protoevangelio de Santiago puede encontrarse en castellano en Santos Otero, pp. 130-170. Sobre los escritos de Nag Hammadi en castellano han aparecido ya tres volúmenes, publicados por Piñero, A.-Montserrat, J.-García, F., Textos gnósticos. Biblioteca de Nag Hammadi, Vol. I + II + III. Muchos de estos textos han sido revalorizados por los investigadores, sobre todo norteamericanos, del denominado Third Quest sobre el Jesús histórico. Pero muchos autores no están de acuerdo con la valoración más bien positiva de estos textos, que hace este grupo de autores. 
En todo caso, y como señala Pagels"s, "si admitimos que algunos de estos cincuenta y dos textos [encontrados en Nag Hammadi] representan formas primitivas de las enseñanzas cristianas, puede que tengamos que reconocer que el cristianismo primitivo es mucho más diverso de lo que se creía antes de que se llevasen a cabo los citados descubrimientos". Y añade a continuación ${ }^{27}$ : "Aunque nos parezca diverso y complejo, es posible que, en realidad, el cristianismo contemporáneo muestre una unanimidad mayor que el de las iglesias cristianas de los siglos I y II. Porque casi todos los cristianos desde aquella época, católicos, protestantes u ortodoxos, han compartido tres premisas básicas: (1) aceptan el canon del Nuevo Testamento; (2) confiesan el credo apostólico; y (3) afirman formas específicas de institución eclesiástica. Pero cada uno de estos elementos - el canon de las Escrituras, el credo y la estructura institucional - surgió en su forma actual sólo hacia las postrimerias del siglo II".

Pagels $^{28}$ concluye su presentación de los evangelios gnósticos con la siguiente constatación:

Durante la formación del cristianismo surgieron conflictos entre, por un lado, aquella gente inquieta, inquisitiva [se refiere a los "gnósticos"], que señalaba una senda solitaria de autodescubrimiento $y$, por otro, el marco institucional que daba a la gran mayoría de la gente una sanción religiosa y una dirección ética en sus vidas cotidianas. Adaptando a sus propios fines el modelo de la organización política y militar de los romanos, y granjeándose el apoyo imperial en el siglo IV, el cristianismo ortodoxo se hizo cada vez más estable y duradero. El cristianismo gnóstico no pudo con la fe ortodoxa, ni en lo que se refiere al amplio atractivo popular de la ortodoxia, lo que Nock denominó su "correspondencia perfecta por inconsciente a las necesidades y aspiraciones de la humanidad corriente ${ }^{29}$, ni en lo que respecta a su organización efectiva. Ambas cosas han asegurado su supervivencia a través de los tiempos. Pero el proceso de instauración de la ortodoxia excluyó todas las demás opciones. El gnosticismo, que ofrecía altemativas a lo que se convertirfa en el empuje principal de la ortodoxia cristiana, fue suprimido, con lo cual la tradición cristiana resultó empobrecida".

26. Op. cir., p. 22.

27. Ibid.

28. Op. cit., pp. 203s.

29. A.D. Nock, "The Study of the History of Religion", en Arthur Darby Nock, Essays on Religion and the Ancient World, ed. Z. Stewar, Cambridge, 1972, p. 339. 


\section{Importancia de la creación del género literarto "evangelio" y de la lite-} ratura del Nuevo Testamento como testimonio "normativo" o "canónieo" para toda Iglesía cristiana

El evangelio canónico de Lucas, a finales de los años 80 , se hace eco de los intentos por comunicar la tradición de Jesús de Nazaret de un modo que él considera manipulador y deformado ( $c f$. Lc 1, 1-4). Por eso, considera necesario "investigar cuidadosamente todo lo sucedido desde el principio" y hacer "una exposición ordenada" de las tradiciones sobre Jesús. Esta preocupación lo llevó, entre otras cosas, a incorporar el evangelio de Marcos y las tradiciones de la "fuente Q" a su obra. En su concepción, el género literario evangelio, creado por Marcos, posibilitaba dos cosas, que son para él esenciales para la fe cristiana. Por un lado, recuperar la vida de Jesús de Nazaret en su concreción, una vida que lo llev6 a la muerte, condenado por las autoridades de su época. Pero, por otra, leerla e interpretarla a la luz de la resurrección de Jesús, que les abrí́ los ojos para comprender el significado de esta vida y de las Escrituras del Antiguo Testamento, que la iluminaban (cfr. Lc 24, 25-26.44-45). Al ponerlo todo por escrito se evitaba que las tradiciones sobre Jesús pudieran ser manipuladas y deformadas, sin que el lector pudiera caer en la cuenta de ello.

De hecho, no sabemos concretarnente a qué tradiciones literarias se refiere Lucas, en el prólogo a su evangelio. Pero hay un elemento que parece común a los evangelios, que las grandes iglesias cristianas no aceptaron como inspirados por Dios y, por tanto, como nomativos ("canónicos") dentro del Nuevo Testamento. Me refiero al hecho de que estos evangelios, que la tradición de las grandes iglesias denomina "apócrifos", además de dar primacía a menudo a lo que resulta (excesivamente) "maravilloso", poco humano, en la vida de Jesús, no suelen situar las palabras de Jesús en el marco de su vida concreta, que lo lievó a la cruz. No cuentan que lo que lo llevó a la cruz fue su opción por los pobres y su denuncia de todas las estructuras religiosas, políticas, económicas y sociales, que no ponen el bien del ser humano como expresión máxima y criterio de discernimiento de la voluntad de Dios.

Precisamente, este aspecto había sido el gran descubrimiento y aportación teológica de Marcos ${ }^{30}$, el primero que escribió el tipo de obra que él denominó evangelio o "Buena noticia", que es lo que la palabra griega eu-angelion significa (cfr. Mc 1, 1: "Comienzo de la buena noticia de Jesús, Mesías, Hijo de Dios"). Por lo que sabemos, Marcos fue el primero que situó las tradiciones sobre Jesús en el marco "biográfico" de su vida. Una vida que, por su orientación al bien del ser humano y su denuncia de la injusticia, ya desde el inicio (cfr. Mc 3, 1-6) estuvo marcada por la sombra de la cruz.

30. Cfr. X. Alegre, "Marcos o la corrección de una ideología triunfalista", Revisfa Latinoamericana de Teología, 2 (1985), 229-264 (también en Memoria, pp. 87-130). 
Con ello, Marcos hizo una gran aportación literario-teológica. Pues al situar los textos de Jesús en el contexto de su vida concreta, evitó que se les pudiera convertir en pretexto para hacerles decir lo que a una persona o grupo concreto le interesara Ya que, como decía un amigo mío, "un texto fuera de su contexto no es más que un pretexto". A la vez, al fijar por escrito las tradiciones, concatenándolas entre si, proporcionó una pista de lectura fundamental, que posibilitara una mejor comprensión de cada uno de los textos en concreto. Pues, como señala con razón la investigación lingüística, en literatura, "el todo está antes que las partes" y permite su comprensión adecuada ${ }^{3 !}$.

En cambio, un evangelio gnostizante, como el Evangelio de Tomás, no tiene ningún interés por recuperar el marco de la vida concreta de Jesús. Se limita, simplemente, a recoger palabras sueltas del Maestro de Nazaret. Ello le permite interpretar a su aire la "parábola de la oveja perdida", que encontramos también en Mateo 10, 10-14 y en Lucas 15, 3-7. Según el logion o palabra 107 del Evangelio de Tomás, "el reino es semejante a un pastor que tenfa cien ovejas. Una, la más grande, se perdió. Él, entonces, dejo las noventa y nueve y buscó la otra hasta que la encontro. Tras el esfuerzo, le dijo: Te quiero más ${ }^{32}$ que a las noventa y nueve". Al omitir el contexto de la vida concreta de Jesús y su opción por los pobres y marginados, le es posible al autor de este evangelio cambiar la "Iógica" de Jesús, sin que el lector se dé cuenta necesariamente de ello.

En Mateo, en cambio, el pastor va a buscar la oveja simplemente porque está perdida. Y con ello se justifica, por el contexto (cfr. Mt 18, 1ss), la valoración y la defensa que hace Jesús de los pequeños, algo que encaja perfectamente con la "lógica" de Jesús, que aparece en los cuatro evangelios canónicos. Algo semejante ocurre en Lucas. En él (cfr. Lc 15, 1-2), la parábola sirve para justificar que Jesús vaya a buscar, coma con los pecadores y publicanos, despreciados por los que se creían piadosos y mejores ${ }^{33}$. En la misma línea hay que colocar la crítica que Jesús, a continuación, hace del hermano mayor de la "parábola del hijo pródigo", que desprecia a su hermano pequeño que ha abandonado la casa del padre y no se alegra con su regreso, como se alegra el Padre (cfr. Lc 15, 11-32).

31. "La aproximación literaria se pregunta por la fuerza del conjunto. Aun cuando un estudio literario concreto se centre en un texto minúsculo, sitúa siempre el fragmento en el contexto inmediato y en el conjunto del escrito. Su esfuerzo es penetrar el sencido del fragmento concreto yendo en su estudio de la parte al todo y del todo a la parte. Esto permite una percepción mejor del significado de una obra literaria, boblica o no, y de cada una de sus partes" (J. P. Tosaus, La Biblia como literatura, Estella, 1996, p. 30.

32. Los subrayados son míos.

33. Cfr. X. Alegre, "La parábola de la oveja perdida según los evangelios de Marcos y de Luces. Modelos inspirados de actualización del mensaje de Jesús", en Memoria, pp. 263-278. 


\section{El Apocalipsis de Juan, escrito cristiano de resistencia frente al imperio romano}

No quiero terminar esta introducción al Nuevo Testamento, que tiene especialmente en cuenta su aportación como literatura, sin aludir, de forma breve, a otro tipo de literatura que encontramos en él. Se trata de una literatura llena de imágenes abigarradas y difíciles de entender para el lector $u$ oyente no iniciado. Pero es una literatura muy importante y popular, en la época en que se escribió el Apocalipsis de Juan. Me refiero a la literatura apocalíptica.

¿Por qué este libro es tan simbólico y difícil de comprender? Es esencial saber, para poderlo comprender, que la literatura apocallptica es una literatura de resistencia, escrita por los "guerrilleros de la fe", que invitan a la comunidad judía o cristiana a resistir frente a las amenazas y persecuciones del imperio de turno. Y a mantener viva la esperanza de que Dios, que es el auténtico Señor de la historia, acabará haciendo justicia a los creyentes y pedirá cuentas al imperio injusto por los males que ha hecho ${ }^{34}$.

La literatura apocalíptica bíblica floreció en tiempos de la persecución religiosa, que sufren las comunidades judía ( $c f r$. Daniel, 2 Baruc o Baruc sirfaco, 4 Esdras) y cristiana (Mc 13; Mt 24; Lc 21; Apocalipsis de Juan).

En el caso de Apocalipsis de Juan, su autor hace referencia a la persecución por parte de Roma (el Ap 13 y 17-18 la denomina "la Bestia", la "gran prostituta", "Babilonia"), que viven las comunidades juánicas, en tiempo de Domiciano (hacia el $96 \mathrm{~d}$. C.). El profeta Juan, autor del libro, aplica al emperador la leyenda del "Nerón redivivo" (cfr. Ap 13, 3 y 17, 9-11). Y le aplica la cifra 666, en Apocalipsis 13,18, indicando que "el inteligente" puede calcular a quien se refiere la cifra (la suma de las letras hebreas de las palabras "Nerón César" da la cifra 666).

Es verdad que la comunidad cristiana está sufriendo mucho. Hay mártires (cfr. Ap 2, 13). De ahr la queja de éstos en Apocalipsis 6, 10-11:

Señor santo y veraz, ¿cuándo nos harás justicia y vengarás la muerte sangrienta que nos dieron los habitantes de la tierra? Se les entrego entonces un vestido blanco a cada uno y se les dijo: "Aguarden un poco todavía. Aguarden hasta que se complete el número de sus compañeros y de sus hermanos que, como ustedes van a ser martirizados".

El imperio romano parece todopoderoso (cfr. Ap 13, 1-10) y margina, a través de sus colaboradores (la propaganda, etc.: cfr. Ap 13, 11-17), a todos los que no adoran sus principios y valores, representados por el emperador:

34. Véase una explicación más amplia del significado del Apocalipsis de Juan en mi artículo: "El Apocalipsis, memoria subversiva y fuente de esperanza para los pueblos 
Seducfa a los habitantes de la tierra con los prodigios que se le había otorgado realizar en favor de la primera bestia, y los incitaba a erigir una estatua en honor de la bestia que sobrevivió a la herida de la espada. Se le concedió dar vida a la estatua de la bestia, de modo que incluso pudiese hablar, y se le dio poder para hacer morir a cuantos no adorasen la estatua de la bestia. Hizo también que todos, chicos y grandes, ricos y pobres, libres y esclavos llevasen tatuada una marca en la mano derecha o en la frente. Y solo quien llevaba tatuado el nombre de la bestia o la cifra de su nombre podfa comprar o vender (Ap 13, 14-17).

Pero el Apocalipsis quiere dar un mensaje de esperanza, una "buena noticia eterna" (Ap 14,6). La buena noticia es que Dios $-y$ no Domiciano- es el auténtico "señor" de la historia. $\mathrm{Y}$ ha dado todo su poder a Jesús, muerto y resucitado (representado por la imagen del "cordero degollado de pie ante el trono de Dios", cfr. Ap 5). Y Roma, como todo imperio injusto a lo largo de la historia, acabará cayendo (cfr. Ap 16, 17 - 18,24). En este sentido, los males no durarán más de 42 meses o 1260 días (cfr. Ap 11, 2-3), que es el equivalente a tres años y medio, la mitad de siete, que es el número perfecto, de plenitud. El Apocalipsis, por tanto, no predice la duración exacta de los males (según Ap 13, 32, ni el Hijo sabe cuándo será el fin del mundo), sino que dice algo equivalente a nuestro refrán "no hay mal que cien años dure".

Pero la historia no es el eterno retorno de todas las cosas, sino que, guiada por Dios, avanza hacia una meta positiva. Por eso, al final de la historia se anuncia la utopía de la nueva creación, en la que el mal y el dolor habrán cesado, porque Dios hará nuevas todas las cosas:

Y vi un cielo nuevo y una tierra nueva. Habran desaparecido el primer cielo y la primera tierra y el mar ya no existía. Vi también bajar del cielo, de junto a Dios, a la ciudad santa, la nueva Jerusalén, ataviada como una novia que se adoma para su esposo. Y oí una voz potente, salida del trono, que decía: "Ésta es la tienda de campaña que Dios ha montado entre los hombres". Habitara con ellos, ellos serán su pueblo y Dios mismo estará con ellos. Enjugará las lágrimas de sus ojos y no habrá ya muerte, ni luto, ni llanto, ni dolor, porque todo lo viejo se ha desvanecido. Y dijo el que estaba sentado en el trono: "He aquí que hago nuevas todas las cosas" (Ap 21, 1-5).

Todo el libro, por tanto, quiere ser una explicación teológica de la historia y de cómo se pasa de la Iglesia militante en la tierra, mezcla de bien y de mal (cfr. Ap 2-3), a la Iglesia triunfante en el cielo ( $c f r$. Ap 21, $1-22,5$ ). Para ello es fundamental que, en un mundo injusto, en el que las diversas fuerzas positivas y

enucificados", Revista Latinoamericana de Teologfa, 26 (1992), 201-230.293-324 (ahora también en mi libro Memoria, pp.25-86). 
negativas están siempre en lucha (cfr. Ap 12), la Iglesia, consciente de su vocación profética (cfr. Ap 11), que brota de la asimilación del librito que simboliza el evangelio ( $c f r$. Ap 10), se movilice contra los falsos valores representados por el imperio romano. Esto es lo que simbolizan las trompetas del tercer septenario del Apocalipsis (8, 2 - 14, 5).

Se comprende que un mensaje tan subversivo para el imperio romano tenga que ser cifrado, tenga que ser escrito en clave. No conviene que los espías del imperio lo puedan comprender fácilmente. Y si está escrito en clave simbólica es para que el cristiano tome conciencia de que mientras estemos en este mundo, tan marcado por la injusticia, el imperio, aunque caiga, siempre vuelve a reencarnarse en otro imperio y, por tanto, hay que estar siempre sobre aviso, por fidelidad al evangelio de Jesús de Nazaret, muerto y resucitado para dar fuerza a nuestro amor solidario con los pobres y a nuestra esperanza de que "otro mundo, otra globalización, diríamos hoy, es posible".

\section{A modo de conclusión}

El reconocimiento de que el Nuevo Testamento es esencialmente literatura, invita a tomar en serio lo que esto significa. Por ello, cuanto mejor se conoce la literatura, más se puede profundizar en el significado del Nuevo Testamento, evitando lecturas "fundamentalistas" del mismo. $\mathrm{Si}$, como señala el Concilio Vaticano II, en su Constitución Dei Verbum (n. 13), "las palabras de Dios, expresadas en lenguas humanas, se han hecho semejantes al lenguaje humano, a la manera como un día el Verbo del Padre etemo, al tomar la carne de la flaqueza humana, se hizo semejante a los hombres", resulta evidente, entonces, que, el Nuevo Testamento, en cuanto auténtica palabra humana, participa de las características propias de un texto literario y sus textos son comparables a los grandes textos de la literatura universal.

Y termino con una cita de José Pedro Tosaus, que recuerda el influjo extraordinario que ha tenido la Biblia en la literatura, reflejo, a su vez, del influjo que la literatura ha tenido en la Biblia:

Existe una importante influencia de la Biblia en la literatura occidental de todos los tiempos. Una influencia que se deja ver en las leyendas biblicas recogidas por el Cantar del Mío Cid o por el Arcipreste de Talavera, y que constituye una importante fuente de inspiración para autores clásicos y modernos en todas las literaturas de cultura cristiana ${ }^{35}$.

Recuperar la literatura bíblica, incluyendo el Nuevo Testamento, saber interpretarla adecuadamente, es recuperar la memoria histórica del pueblo de Dios cristiano. Pero no se trata de una memoria cualquiera. Como muy bien pone al

35. Op. cit., p. 183. 
descubierto el libro del Apocalipsis, se trata de una memoria subversiva y fuente de esperanza para los pueblos crucificados ${ }^{36}$.

36. Cfr. supra n. 34. 